Review

\title{
Review of Impact Factors of the Velocity of Large Hailstones for Laboratory Hail Impact Testing Consideration
}

\author{
Christian Dieling*(D), Milton Smith and Mario Beruvides \\ Department of Industrial, Manufacturing and Systems Engineering (IMSE), Texas Tech University, \\ Lubbock, TX 79409-301, USA; milton.smith@ttu.edu (M.S.); mario.beruvides@ttu.edu (M.B.) \\ * Correspondence: christian.dieling@ttu.edu
}

Received: 1 November 2020; Accepted: 9 December 2020; Published: 15 December 2020

\begin{abstract}
The terminal velocity of hailstones is an essential quantity in hail research. It is an important value for the kinetic energy of hailstones and has to be carefully considered when laboratory hail impact testing is being planned. Many standardized hail impact testing procedures require specific impact velocities. Several empirical models for various hailstone diameter ranges have been developed to calculate the velocity based on the diameter, indicating somewhat inconsistent results. The velocity is influenced by factors such as their density, drag coefficient, shape or air density, and strong winds. This article takes a closer look into each of these factors and how they influence the velocity of hailstones and the damage potential of hailstorms. Implications are made for laboratory testing of hail impact testing procedures and how the geographic location of hailstorms might be a considerable factor when designing a test.
\end{abstract}

Keywords: hail; hailstone; terminal velocity; testing; impact; velocity

\section{Introduction}

The terminal velocity of hailstones is a crucial consideration in hail-related research. It is part of a given hailstone's kinetic energy that plays a role in identifying the intensity of a hailstorm [1-3] and is a significant value in determining the damage potential of a given hailstone [1,2]. The kinetic energy of hailstones is also used for the calibration of hailpads [4]. In the field of material testing, tests are often performed to comply with standards. For these tests, it is essential to know about the typical terminal velocities of different hailstone sizes. This paper provides an overview of different approaches to the hailstone velocities used in various testing procedures. It also examines the terminal velocity of hailstones and identifies factors that influence it. Factors for the desired consideration of impact speeds in a laboratory testing environment are illustrated. Additionally, factors involved in the theoretical calculation of the terminal velocity, such as the hailstone's density, drag coefficient, shape, and air density, are examined. The complexity of the impact factors on the terminal velocity theoretical calculation leads to an overview of different empirical models. Additionally, the effect of wind on the impact velocity of hailstones is also analyzed.

The intensity of various hailstorms can be quantified by the hail's kinetic energy that accompanies the storm [2] and by the diameters of the most massive hailstones within a hailstorm [1]. The TORRO (Tornado \& Storm Research Organization) Hailstorm Intensity Scale uses these factors [3]. When speaking about hailstones' size, the World Meteorological Organization (WMO) recommends a maximum dimension larger than $5 \mathrm{~mm}$ as the cut-off to distinguish hail from graupel [5]. For a thunderstorm to be classified as severe, the U.S. National Weather Service establishes a maximum dimension of hail of at least one inch $(2.54 \mathrm{~cm})$ [6]. The term "gargantuan hail" was recently proposed 
for hailstones with maximum dimensions exceeding $15 \mathrm{~cm}$, representing the upper limits of currently known hailstone sizes [7].

Impact testing for structures usually deals with larger hailstone sizes, as the size is closely connected to the damage inflicted on ground structures [8]. Structural damage results from a sufficiently high kinetic energy. The threshold size for hailstones to damage structures, especially roofs, is given as 3.81 to $5.08 \mathrm{~cm}$ (1.50 to 2.00 Inches) $[9,10]$. These threshold sizes vary based on the roofing material but seem to be reasonable estimates for a wide range of materials [11].

The kinetic energy of an object is calculated from its movement or velocity and its mass. For a hailstone, this movement originates from gravity, and its final velocity is a combination of the terminal velocity and a wind component, a relationship that will be discussed in this review.

\section{Hailstone Properties in Current Standard Testing Procedures}

Test standards for hail impact testing include ASTM F320, which deals with the hail impact resistance of aerospace transparent enclosures, ASTM E822 used to determine the resistance of solar collector covers to hail, ASTM E1038 to determine the resistance of photovoltaic modules to hail, as well as FM 4473 and UL 2218 which are concerned with the impact of hail on roofing materials. Complying with these standards, such as those set by ASTM International, formerly known as the American Society for Testing and Materials, and other institutions, the testing procedure requires measuring the projectile's velocity and several other measurements. Information on impact speed is obtained by the use of laser sensors [12].

For hail simulation, most of the before-mentioned testing procedures use artificially made freezer ice balls using molds [13-16]. UL 2218 is an exception, as it uses steel balls that are dropped onto the test specimen [17]. The use of ice spheres implies the use of an assumption that is often seen in hail research. It is assumed that the density of hail is close to that of pure ice [18-21]. Some testing procedures introduce different impact modes and densities of ice spheres to model a broader range of real hailstone properties [22]. The use of steel is based on the assumption that damage potential is closely related to the kinetic energy upon impact [9]. While more comfortable to handle than ice spheres, different materials such as steel have their flaws. Steel creates different damage profiles compared to those of ice spheres $[23,24]$.

Using spherical molds or spheres of different materials also means that the test procedures are unable to accommodate for the various complex shapes that can be observed in real hailstones [25-27] that affect the drag coefficient. The effect of this factor is investigated further in this research. Another vital factor of hailstone velocity investigated in this review is air density. The test procedures do not mention this factor explicitly. UL 2218 comes close to considering this factor by requiring the specific temperature of the testing environment, as the air density is related to its temperature and pressure [28].

\section{The Terminal Velocity of Hailstones}

The terminal velocity of a hailstone is influenced by several factors, such as the density of the hailstone, air density, and the Reynolds number and drag coefficient that are based on the shape and size of the hailstone itself. It also involves atmospheric environment data such as air density, viscosity, and gravitational acceleration, suggesting that the terminal velocity depends on the geographic location of the hailfall [29]. To acquire a theoretical terminal velocity $v_{t}$ for a given hailstone, an equation derived from the net force that, based on the drag force, acts on a solid object can be used.

$$
v_{t}=\left(\frac{2 \times m \times g}{A \times C_{d} \times \rho_{a}}\right)^{0.5}
$$

In Equation (1), $m$ denotes the mass of the object, the hailstone, $g$ denotes the acceleration due to gravity, $\rho_{a}$ the air density, $A$ describes the cross-sectional area of the hailstone normal to the airflow, and denotes $C_{d}$ the drag coefficient [30]. An assumption that has often been made for hailstones is a 
spherical shape. If this assumption is applied to the equation above, the expression for the terminal velocity of such a hailstone becomes

$$
v_{t}=\left(\frac{4 \times g \times \rho_{h} \times D}{3 \times C_{d} \times \rho_{a}}\right)^{0.5}
$$

with $D$ being the diameter of this sphere and the density of this hailstone $\rho_{h}$ [30-33]. When the terminal velocity of hailstones is discussed in theory, this equation is often calculated and used. It is a theoretical model that only holds if a variety of assumptions are fulfilled. Many of the properties that have an impact on the terminal velocity of the hailstone, such as size, shape, density, and other relevant factors, can have a wide range. The following sections closely examine these factors and how they influence the actual velocity obtained by the equation.

\subsection{Density of Hailstones}

The first factor is the density of a hailstone. There is a "comparatively high density of hail grown in warm-weather" [20]. Additionally, in "almost all of the hailstones a general decrease in density is noticeable from the periphery toward the center" [34]. There is also evidence for amorphous inner cores in hailstones with a significantly lower density than the outside layer [35]. There are not only reports of a range of densities within a single hailstone, but the known literature also reports a wide range of densities for different hailstones. At the lower end, a density of $0.45 \mathrm{~g} \mathrm{~cm}^{-3}$ was observed as the "mean density of conical graupel" [36]. Earlier observations found densities for soft graupel ranging from 0.5 to $0.7 \mathrm{~g} \mathrm{~cm}^{-3}$ [37]. Densities of 0.8 to $0.9 \mathrm{~g} \mathrm{~cm}^{-3}$ have been measured [38]. A slightly closer range was found for the mean density values of hailstones between 0.82 and $0.87 \mathrm{~g} \mathrm{~cm}^{-3}$ [34]. These are all less than the density of pure ice. Due to its open molecular structure, the density of pure ice at $0{ }^{\circ} \mathrm{C}$ is $0.917 \mathrm{~g} \mathrm{~cm}^{-3}[39,40]$. Looking at larger hailstones with a more devastating effect on structures, it was found that the mean density is often closer to $0.9 \mathrm{~g} \mathrm{~cm}^{-3}$ [20]. Some even mention that large, heavy hailstones have a density close to that of pure ice [21]. Three-dimensional scanning technology, in recent research, supports a density close to pure ice for larger hailstones [41]. The density of hailstones is an essential factor for the investigation of the terminal velocity of hailstones. Because of the large variety of properties, the exclusive use of diameter is a limited approach to predicting the terminal velocity. For material testing with a focus on larger, more devastating hailstones, the assumption of density close to pure ice is often used.

While precise relationships between the density and strengths are not fully known [41], it is said that softer low-density hailstones have a lower damage potential [42]. Aside from the kinetic energy upon impact, such properties of a hailstone may have the most significant effect on its damage potential [43]. Reports can be found in which hailstones are described as soft or slushy [44-46].

\subsection{The Drag Coefficient and Reynolds Number}

The terminal velocity of a hailstone is also influenced by its drag coefficient. The drag coefficient is a dimensionless value that varies between different reference areas. The "reference area for a sphere can be taken as the square of the diameter $\mathrm{d}^{2}$ or as the frontal area $(1 / 4) \pi \mathrm{d}^{2 \prime \prime}$ [47], and it is proportional to this reference area, the square of the velocity, and the air density [47]. The drag coefficient and the Reynolds number are dependent on each other [48,49]. There is "a trend towards a decreasing drag coefficient with an increasing Reynolds number" [30]. The drag coefficient, being part of the equation for the terminal velocity of a hailstone, becomes problematic when the drag coefficient is assumed to be specific to a single hailstone [19]. The drag coefficient usually ranges between 0.4 and 0.6 [50], or even from 0.45 up to 0.8 [51], depending on the size and the surface roughness of the given hailstone. A good fit over a considerable size of hailstones for the drag coefficient was found to be a value of 0.6 , especially if hailstones are approximately spherical [52,53]. 
This value of 0.6 for the drag coefficient has also been stated for hailstones that are not smooth spheres but have a diameter larger than $1.00 \mathrm{~cm}$ [51]. A recent observational study found that rough spheres appear to have a drag coefficient that is closer to 0.4 rather than 0.6. [49]. This research also found that the drag coefficient for natural hail with non-spherical shapes, represented by the equivalent spherical diameter, rather than the maximum diameter, is much closer to 0.8-1.0 [49]. Earlier studies show that the non-spherical shape of hailstones, as well as the variable surface roughness of hailstones, results in the assumption of 0.55 as a reasonable value for the drag coefficient for real hailstones [31]. The significant influence of the non-spherical shape on the individual drag coefficient is demonstrated in research results from lobed hailstones. Experiments performed with three-dimensional printed lobed hailstone models in a laminar airstream indicated a significant influence of the surface characteristics on the drag coefficient [54]. These effects were different based on the number and size of lobes. However, while the number of lobes on the 3D printed models does not reveal an influence on the drag coefficient [54], this is in disagreement with a numerical study conducted a few years earlier [55]. Their results show that the drag coefficients of long, lobed hailstones with 32 and 72 lobes tend to be above that of spherical hailstones, while those with eight lobes have mostly a drag coefficient below that. [55] Further numerical investigation of lobed hailstones also revealed that larger lobed hailstones of above 3 to $10 \mathrm{~cm}$ in diameter have a larger ventilation effect than spherical hailstones of the same size. [56]

The melting process of a hailstone falling through the air also changes its drag coefficient [57]. The various different shapes, surface roughness, melting, changing cross areas due to tumbling of a hailstone make reliable predictions on the drag coefficient very difficult.

Figure 1 shows the terminal velocities for hailstones of different diameters based on Equation (2) for drag coefficients of 0.45 as the lower end, 0.60 as the typical value for a wide range of hailstones, and 0.80 as the upper end of the spectrum, to illustrate the influence of this factor on the velocity and therefore its kinetic energy. As stated, the drag coefficient is influenced by the Reynolds number. A Reynolds number (Re)-Best number $(X)$ relationship has recently been used to obtain terminal velocity equations [58]. These equations were plotted as a point of reference. For the other values that are involved in the terminal velocity Equation (2), the density of the hailstone is assumed to be close to pure ice with $\rho_{h}=917 \mathrm{~kg} / \mathrm{m}^{3}$. For the air, a density of $\rho_{a}=1.225 \mathrm{~kg} / \mathrm{m}^{3}$, and the acceleration due to gravity is $g=9.81 \mathrm{~m} / \mathrm{s}^{2}$ is used.

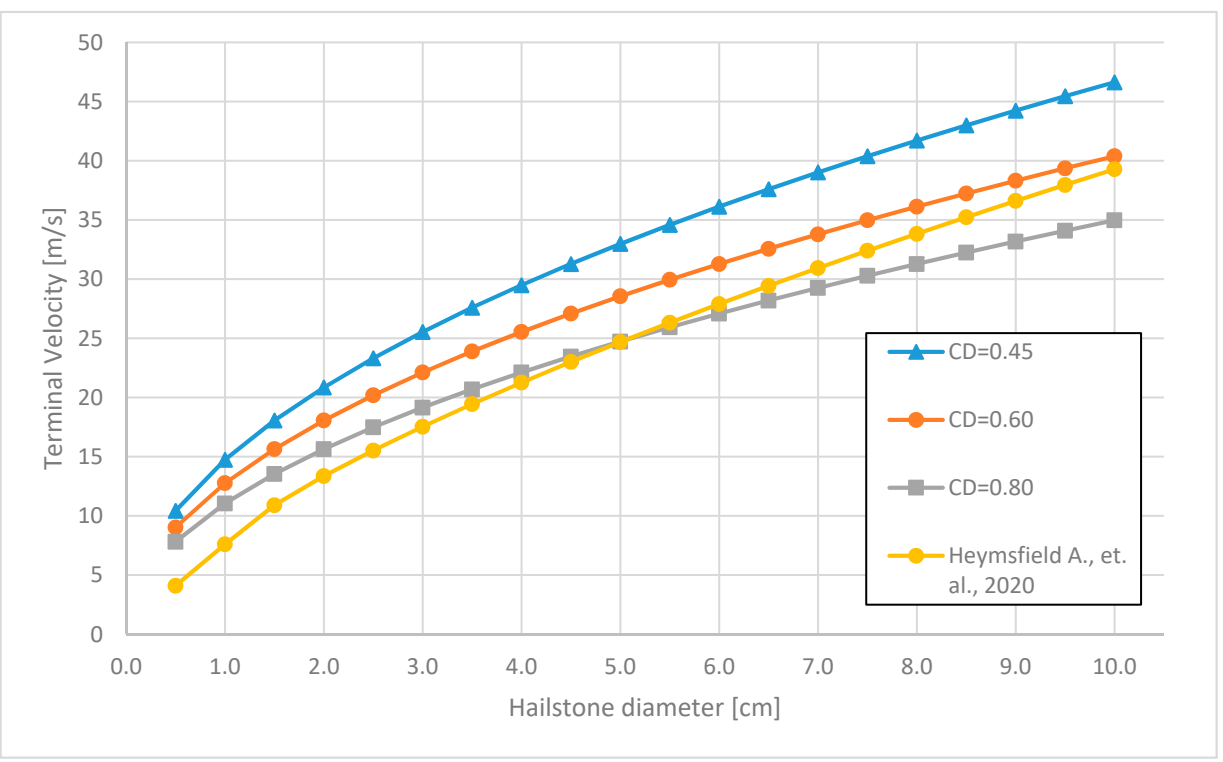

Figure 1. Relationship between spherical hailstone diameter and terminal velocity for different drag coefficients. 
With the density of the hailstone, the air density, and the acceleration due to gravity held constant, the influence of the drag coefficient on the terminal velocity for different sized hailstones can be seen. At a drag coefficient of 0.60 instead of 0.80 , the terminal velocity increases by $15 \%$, and if further reduced to a drag coefficient of 0.45 , it increases by $33 \%$ as compared to the 0.80 value. As the absolute value of the difference in terminal velocity becomes larger with bigger spheres that are more relevant for material testing, this factor becomes important to consider, especially as larger hailstones tend to get less spherical [59] and therefore are expected to have a greater variety in their drag coefficient.

\subsection{The Spherical Shape of Hailstones}

Concerning the drag coefficient of hailstones, it was stated that the specific drag coefficient for an individual hailstone is closely related to its shape. The sphere was often used to describe the shape of most hailstones but was proven to be inadequate in most cases. The assumption of this spherical shape can be used to derive the general formula for the terminal velocity of hailstones. This descriptor of the shape was initially used in hail research to refer to most hailstones [18,60-62]. The assumption of the spherical shape of hailstones was also initially questioned and called for further investigations [27]. Shapes of hailstones have also been described as tooth-shaped or as being the shape of a "cauliflower" [26]. Later, the sphere form of hail is supported in a research paper that labeled $84 \%$ of the hailstones that were examined as spheroids [30]. The majority of hailstones-over $50 \%$ of hailstones-were identified in other studies independent of the geographical location of these stones, supporting the spherical shape as a reasonable assumption for hailstone research [63]. The shape of a hailstone depends on its size and the conditions under which it grows [25]. The shape of a hailstone gets less spherical as its size increases $[59,64]$. An analysis of hailstone shape factors shows that even smaller hailstones are not spherical and that the symmetry of hailstones only decreases with increasing hailstone size [65].

While ice spheres are often used in testing procedures, these shapes are not sufficiently accurate to describe a significant number of real hailstones. It must be noted that the influence of hailstone shape on the impact itself, its damage potential, and if irregularly shaped ice balls should be used for impact tests is beyond the scope of this review.

\subsection{The Effect of Air Density}

The next variable that influences the terminal velocity of hailstones is air density. Air density itself is also influenced by many factors, such as temperature, humidity, and air pressure [28]. The CIPM-2007 formula is often used to calculate the air density as it is known to be one of the most accurate ones [28]. The CIPM-2007 formula follows the CIPM-81/91 formula that was endorsed by the International Committee for Weights and Measures. It was updated after a new determination of the mole fraction of argon [66]. At 1 bar, the air density may vary significantly between $1.341 \mathrm{~kg} / \mathrm{m}^{3}$ at $260 \mathrm{~K}\left(-13.15^{\circ} \mathrm{C}\right)$ and $1.089 \mathrm{~kg} / \mathrm{m}^{3}$ at $320 \mathrm{~K}\left(46.85{ }^{\circ} \mathrm{C}\right)$ [67]. The air density is also affected by the altitude. There is a decrease in air density with an increasing altitude [68,69]. The decrease in the global-mean density by altitude is approximately exponential, with a surface density at sea level of about $1.2 \mathrm{~kg} / \mathrm{m}^{3}$ [69]. This means that with an increase in altitude, the terminal velocity of hailstones also increases [70] if all other factors were to be the same.

Figure 2 shows the terminal velocities for hailstones at different air densities between $0.8 \mathrm{~kg} / \mathrm{m}^{3}$ and $1.45 \mathrm{~kg} / \mathrm{m}^{3}$ based on Equation (2) for hailstones with diameters of $2 \mathrm{~cm}$ to $10 \mathrm{~cm}$ in $2 \mathrm{~cm}$ increments, to illustrate the influence of this factor on the velocity and therefore its kinetic energy. For the other values that are involved in the terminal velocity equation, the density of the hailstone is assumed at $\rho_{h}=917 \mathrm{~kg} / \mathrm{m}^{3}$, the drag coefficient is assumed to be $C D=0.60$, and the acceleration due to gravity is $g=9.81 \mathrm{~m} / \mathrm{s}^{2}$. 


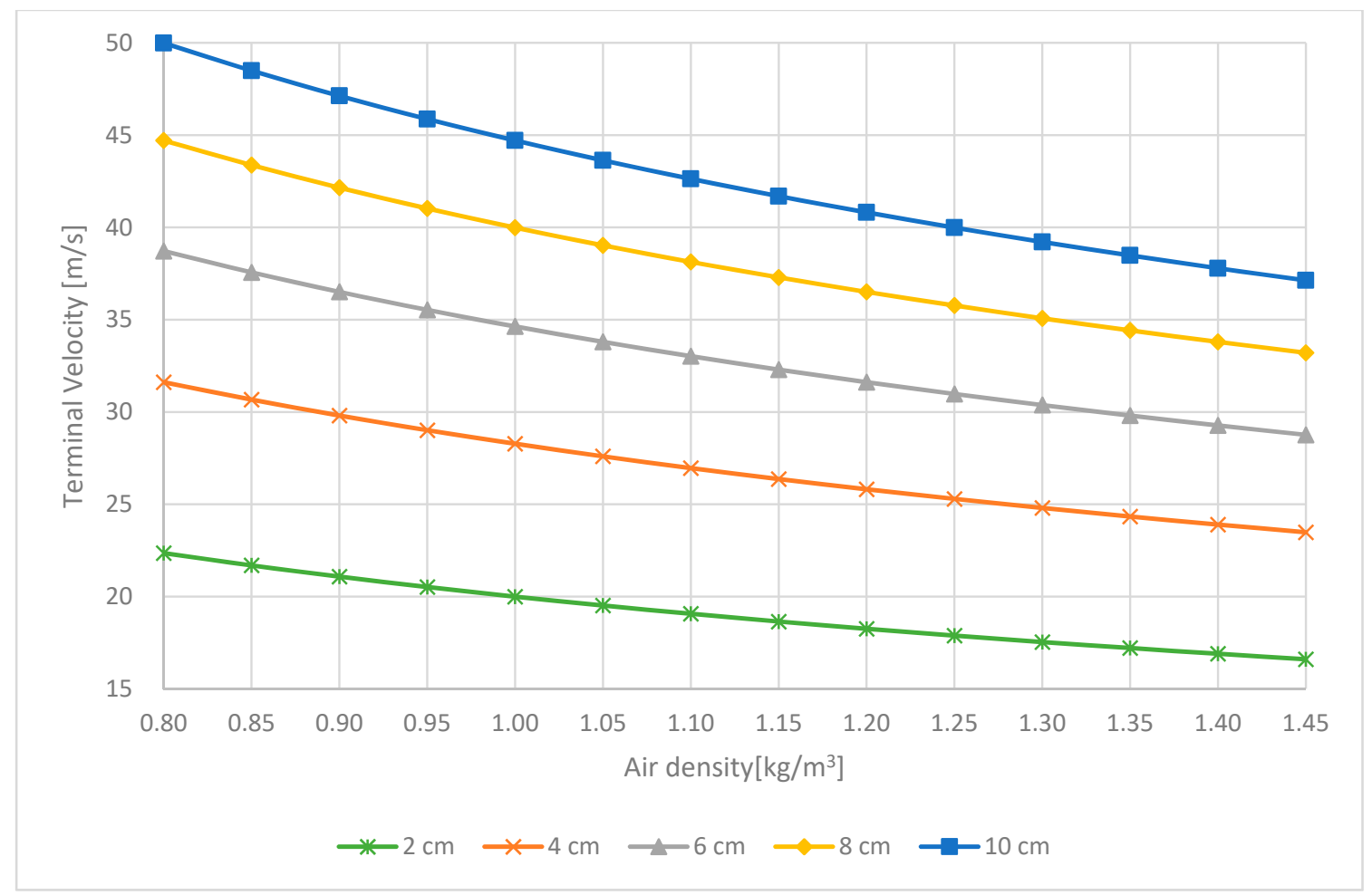

Figure 2. Terminal velocity of different sized hailstones (diameter in $\mathrm{cm}$ ) at varying air densities.

Within the illustrated range of air density, the terminal velocity decreases by $25.7 \%$ independent of the hailstone diameter from an air density of $0.8 \mathrm{~kg} \mathrm{~m}^{-3}$ to $1.45 \mathrm{~kg} \mathrm{~m}^{-3}$. It again illustrates the significant influence of a factor involved in the calculation of the terminal velocity of hailstones.

It suggests that the geographical location of a hailstorm could potentially influence its damage potential. If a hailstorm impacts at ground level but at a location with higher altitudes, such as Denver, $\mathrm{CO}$ with an altitude of 1564 to $1667 \mathrm{~m}$ (5130 to $5470 \mathrm{ft}$ ) [71], where lower air densities are common, this hailstorm might be more severe than the same storm, with other factors unchanged, hitting ground level at lower altitudes and higher air densities, such as Atlanta, GA with an altitude of 225 to $331 \mathrm{~m}$ (738 to $1086 \mathrm{ft}$ ) [71].

\subsection{Empirical Models to Determine Terminal Velocity}

It is the assumption for drag, the illustrated effect of air density, and other mentioned uncertainties in the calculation of the terminal velocity of hailstones that make it difficult to predict the terminal velocity based on a theoretical model. Additionally, for non-spherical hailstones, the effective terminal velocity can vary up to $49 \%$ compared to the theoretical terminal velocity of a sphere [25].

These uncertainties may be a reason why researchers in the field over time have developed empirical relationships of a hailstone's diameter to its velocity to obtain better estimates of the terminal velocity in $\mathrm{m} / \mathrm{s}$. One method fitted the relation of hailstone diameter to its terminal velocity based on observations [72]. The relationship can be described as $v=9 \times D^{0.8}$ for diameter $D$ in $\mathrm{cm}$ for hailstones up to a size of $8.00 \mathrm{~cm}$, where $\mathrm{v}$ is in $\mathrm{m} / \mathrm{s}$ [73]. This is a model that gives values close to another equation, which is $v=1.4 \times D^{0.8}$ [74] with $D$ in $\mathrm{mm}$ for this equation. Significantly lower terminal velocities come from the equations found by other research groups as they looked at hail with a diameter of around 2.00 to $3.00 \mathrm{~cm}$ (0.79 to $1.18 \mathrm{inch})$. One study noted hailstones as large as roughly $2.50 \mathrm{~cm}$ (0.98 inches) in diameter and used the expression $v=11.45 \times D^{0.5}$, where the diameter $D$ is to be in $\mathrm{cm}$ [30]. The other group determined the expression $v=8.445 \times D^{0.553}(\mathrm{D}$ in cm) specifically fitted for observations of hailstones smaller than a diameter of $2.00 \mathrm{~cm}$ (0.79 inches) [75]. A recent corrigendum based on Insurance Institute for Business and Home Safety (IBHS) measurements derives 
the terminal velocity of hail with $v=7.6 \times D^{0.89}$ for diameters less than $1.50 \mathrm{~cm}$ and $v=8.4 \times D^{0.67}$ for diameters larger than $1.50 \mathrm{~cm}$ [58]. However, another research study used $v=15 \times D^{0.5}$ (with $D$ in $\mathrm{cm}$ ) for spheroidal bodies as an empirical formula for the terminal velocity of hailstones [53]. This equation is very close to the one used nowadays by ASTM International standards. To determine the resistance of solar collector covers to hail, they use $v=14.04 \times D^{0.5}$ (with $D$ in $\mathrm{cm}$ ) [13], and to determine the resistance of photovoltaic modules to hail, they use $v=4.44 \times D^{0.5}$ (for $D$ in $\mathrm{mm}$ ) [14]. While these two equations from ASTM International use $\mathrm{cm}$ and $\mathrm{mm}$ for the diameter $D$, respectively, it is important to note that $v=14.04 \times D_{[\mathrm{cm}]}{ }^{0.5}=4.44 \times D_{[\mathrm{mm}]}{ }^{0.5}$. Figure 3 summarizes the several models discussed previously and shows the terminal velocity of hailstones in $\mathrm{m} / \mathrm{s}$ for specific diameters in $\mathrm{cm}$.

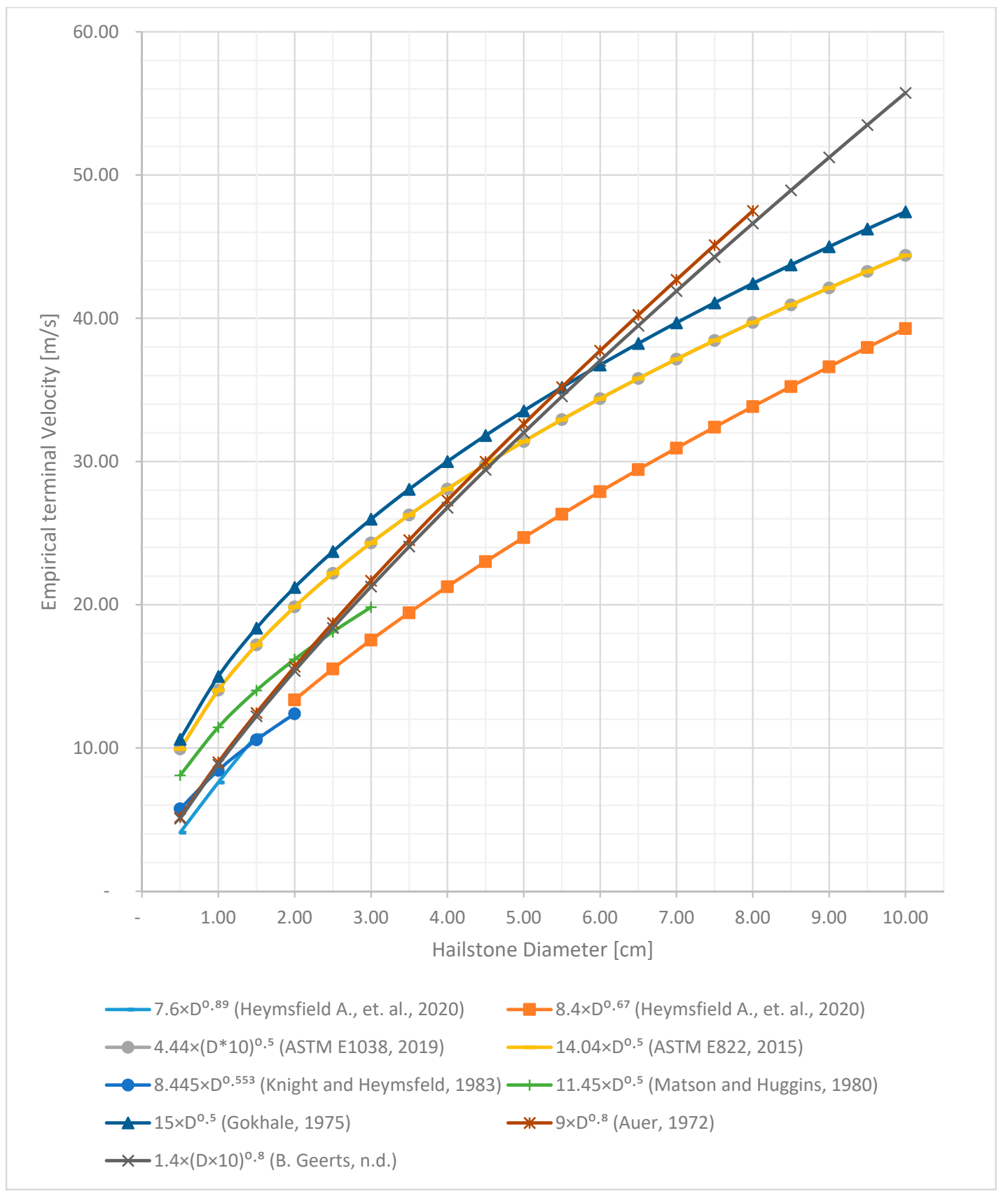

Figure 3. Terminal velocity of hailstones for different empirical models. 
Many of the models estimate a lower terminal velocity for hailstones in the smaller size ranges than the ASTM model. For larger hailstones, the ASTM model indicates the lower end of the velocity range. The different results may well be explained by some of the factors mentioned in this review.

\section{Hailstone Velocity in Combination with Wind}

In many cases, it can be assumed that any given hailstones' terminal velocity is not the actual impact velocity of these hailstones. The resulting impact velocity is influenced by the wind that usually accompanies the falling hail. Hailstorms are a combination of falling hailstones and often strong winds [76]. Some $60 \%$ of hailfall events observed using hail stools had indications for windblown hailstones [77], but it is the total resultant velocity $v_{r}$ of hailstones that is important to determine the kinetic energy upon impact. The accompanying wind during a hailstorm has a direct influence on the total velocity of the hailstone [23] and makes hailfall combined with wind the more damaging type of hailfalls [63]. It is also known that horizontal wind can increase the hailstone velocity above its terminal velocity, which results in a higher impact kinetic energy [8].

Therefore, in combination with wind, hail has a higher damage potential to crops than without the occurrence of wind [46]. Due to this circumstance, wind must be incorporated in the analysis of the total hailstone fall speed. To do this, a horizontal wind component is vectorially added to the vertical terminal velocity $[76,78]$. This wind component can be different at different altitudes and will change the terminal velocity after a time lag as the hailstone acceleration takes time. Another reason supporting this assumption is that hail generally does not fall vertically from the sky but strikes at an angle [62]. Figure 4 shows this relationship between the resultant hailstone velocity $\left(v_{r}\right)$ to a horizontal wind speed component $\left(v_{w}\right)$ component as well as the terminal velocity of a given hailstone $\left(v_{t}\right)$.

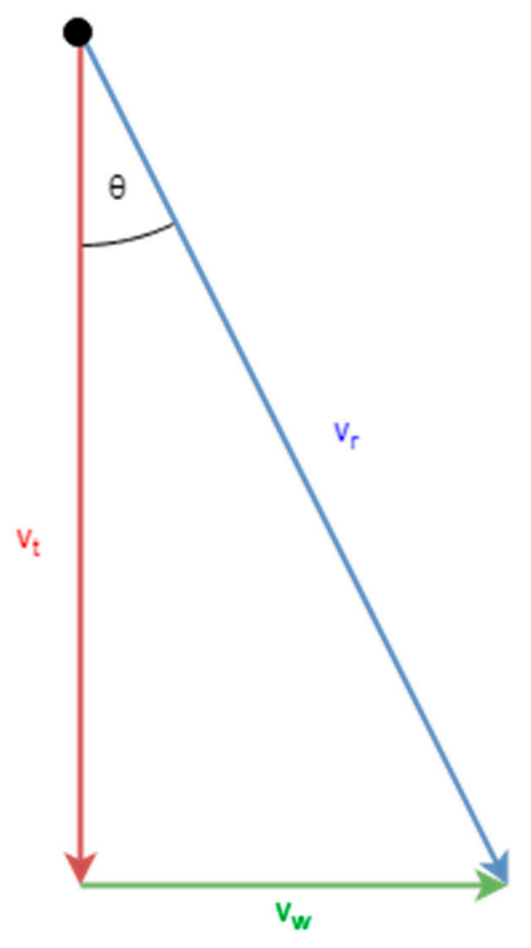

Figure 4. Relationship between the resultant velocity $\left(v_{r}\right)$, wind speed $\left(v_{w}\right)$, and terminal hailstone velocity $\left(v_{t}\right)$.

With this relationship between the terminal velocity of the hailstone itself and the horizontal wind, the total speed can be described by the Pythagorean Theorem. To determine the resistance of solar collector covers to hail impact, ASTM International uses a wind speed of $20 \mathrm{~m} / \mathrm{s}$ [13] or, when determining the resistance of photovoltaic modules from values of $0,15,20$, and $30 \mathrm{~m} / \mathrm{s}$ [14]. 
These values will be used as reasonable assumptions to analyze horizontal wind effects on the resulting velocity of hailstones upon impact.

The actual effect of windblown hailstones depends upon wind direction and the angle at which the structure is installed. If a flat plate solar collector is mounted at $30^{\circ}$ above horizontal and is oriented to the south, a hailstone falling in a wind from the south has an impact velocity near normal and at velocity $v_{R}$. However, if the wind is from the north, the hailstone may have only a glancing impact. A conservative approach in hail impact testing is to take a worst-case approach.

Aside from wind that can be characterized as a horizontal speed vector, there are observations of downdrafts close to thunderstorms. These downdrafts "can speed the descent of the hail to the ground" [79]. There have been observations using Doppler radars that showed fast downdrafts in hailstorms [80]. A particular type of downdraft was observed for the first time in April 1974 and is called a downburst [81]. Tetsuya Theodore Fujita was the first scientist to discover this phenomenon [82] and defined it as "a strong downdraft" that can be "subdivided into macrobursts and microbursts" based on "their horizontal scale of damaging winds" [81]. This effect indicates the existence of a vertical vector of the wind velocity that should be accounted for when looking at the effect of wind on impact velocities. Adding such a vertical wind component to the relationship between the resultant velocity illustrated in Figure 4 results in an overall relationship that is shown in Figure 5.

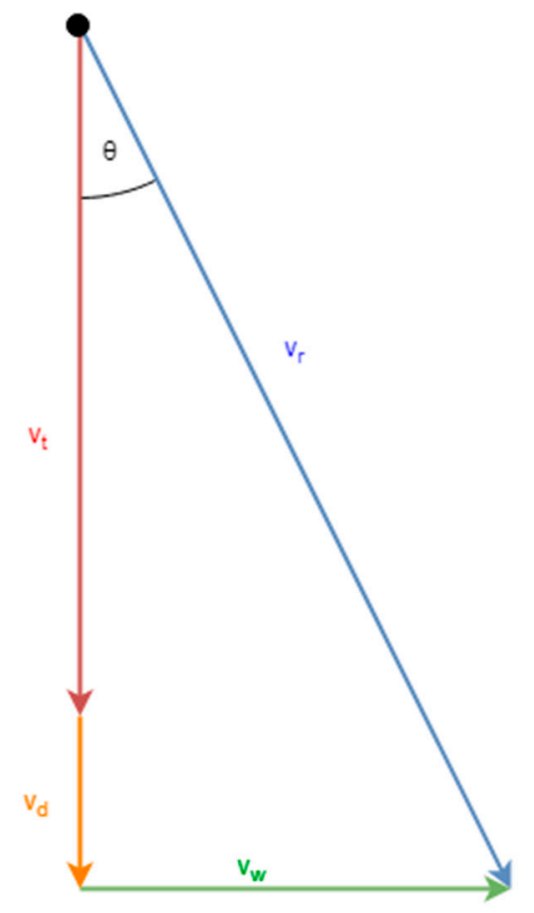

Figure 5. Relationship between the resultant velocity $\left(v_{r}\right)$ including a downburst $\left(v_{d}\right)$.

A microburst is defined as a "strong downdraft that spreads horizontally just above the ground" [83]. A microburst is considered to be a small area and short time phenomenon that is often associated with thunderstorms [83] and known to at times occur in combination with hail [84]. It extends from 1 to $3 \mathrm{~km}$ in diameter and lasts between 5 to $15 \mathrm{~min}$. For an intense microburst, the wind speed can exceed $77 \mathrm{~m} / \mathrm{s}$ [83]. Some numbers give a horizontal expanse of $4 \mathrm{~km}$, a duration of $2 \mathrm{~min}$, and wind speeds of 70-80 m/s [85]. Since their first observation in 1974, microbursts were identified as the cause for some airline crashes [86], making them a dangerous phenomenon. As a type of downburst, the microburst also creates a resulting wind speed that is assumed to be a vector summation of the translation speed or the environmental wind speed with the jet velocity, which is the velocity of the microburst [87]. It is also expected that if a microburst passes over a point, it can change 
the wind direction by 180 degrees [87]. Fujita assumed the downdraft speed to be as high as $5 \mathrm{~m} / \mathrm{s}$ at $10 \mathrm{~m}$ or $10 \mathrm{~m} / \mathrm{s}$ at $20 \mathrm{~m}$ [81].

While Figures 4 and 5 try to show possible effects of horizontal and vertical wind components on a hailstone's resulting speed, they do not represent actual hailstone fall patterns. There are many different types of storms, with complex wind directions and velocity profiles. Wind speed profiles in thunderstorms are known to be complex and difficult to predict. In numerical downburst simulations, it has been shown how the wind speed maximum depends on time and space [88,89]. It is also important to mention that there is proof that storm maximum profiles can vary "considerably between [ ... ] events" [90]. Additionally, the vertical wind shear has been identified as an important factor in the creation of different storm types [79]. The turbulence intensity of a thunderstorm also varies greatly and adds to that complexity [91]. The complexity and variability of the various thunderstorm parameters and the lack of available data make them unpredictable events [92].

To better illustrate the possible effect of different wind directions on a hailstone's resulting impact speed, a theoretical calculation for hailstones with a diameter of $2.00,6.00$, and $10.00 \mathrm{~cm}$ is used. For the calculation, Equation (2) is used, where the density of the hailstone is assumed at $\rho_{h}=917 \mathrm{~kg} / \mathrm{m}^{3}$, the drag coefficient is assumed to be $C D=0.60$, for the air, a density of $\rho_{a}=1.225 \mathrm{~kg} / \mathrm{m}^{3}$ is used, and the acceleration due to gravity is $g=9.81 \mathrm{~m} / \mathrm{s}^{2}$.

Table 1 summarizes the resulting velocities $v_{R}$ of the different sized hailstones for horizontal wind speeds of $0 \mathrm{~m} / \mathrm{s}, 15 \mathrm{~m} / \mathrm{s}, 20 \mathrm{~m} / \mathrm{s}$, and $30 \mathrm{~m} / \mathrm{s}$ and downdraft speeds of $0 \mathrm{~m} / \mathrm{s}, 5 \mathrm{~m} / \mathrm{s}$, and $10 \mathrm{~m} / \mathrm{s}$. The resulting hailstone speed combines the terminal velocity $v_{t}$ and both the horizontal wind speed $v_{w}$ and downdraft speed $v_{d}$ using the following equation

$$
v_{r}=\sqrt{v_{w^{2}}+\left(v_{t}+v_{d}\right)^{2}}
$$

The effect of wind gets less significant for increasing hailstone diameters as the terminal velocity increases diameters get larger. Overall, the effect of wind on the resulting velocity for hailstones appears to be significant and needs to be considered when laboratory hail impact testing is being planned.

Table 1. Effect of vertical and horizontal wind speed on the resulting velocity compared to the terminal velocity of different sized hailstone.

\begin{tabular}{|c|c|c|c|c|}
\hline $\begin{array}{l}\text { Hailstone } \\
\text { Diameter } \\
\quad(\mathrm{cm})\end{array}$ & $\begin{array}{c}\text { Vertical } \\
\text { Wind Speed } \\
(\mathrm{m} / \mathrm{s})\end{array}$ & $\begin{array}{l}\text { Horizontal } \\
\text { Wind Speed } \\
(\mathrm{m} / \mathrm{s})\end{array}$ & $\begin{array}{c}\text { Resulting } \\
\text { Hailstone Velocity } \\
(\mathrm{m} / \mathrm{s})\end{array}$ & $\begin{array}{c}\text { Increase Compared } \\
\text { to Terminal Velocity } \\
(\%)\end{array}$ \\
\hline \multirow{12}{*}{2} & \multirow{4}{*}{0} & 0 & 18.07 & 0 \\
\hline & & 15 & 23.48 & 30 \\
\hline & & 20 & 26.95 & 49 \\
\hline & & 30 & 35.02 & 94 \\
\hline & \multirow{4}{*}{5} & 0 & 23.07 & 28 \\
\hline & & 15 & 27.51 & 52 \\
\hline & & 20 & 30.53 & 69 \\
\hline & & 30 & 37.84 & 109 \\
\hline & \multirow{4}{*}{10} & 0 & 28.07 & 55 \\
\hline & & 15 & 31.82 & 76 \\
\hline & & 20 & 34.46 & 91 \\
\hline & & 30 & 41.08 & 127 \\
\hline
\end{tabular}


Table 1. Cont.

\begin{tabular}{|c|c|c|c|c|}
\hline $\begin{array}{l}\text { Hailstone } \\
\text { Diameter } \\
\quad(\mathrm{cm})\end{array}$ & $\begin{array}{c}\text { Vertical } \\
\text { Wind Speed } \\
(\mathrm{m} / \mathrm{s})\end{array}$ & $\begin{array}{l}\text { Horizontal } \\
\text { Wind Speed } \\
(\mathrm{m} / \mathrm{s})\end{array}$ & $\begin{array}{c}\text { Resulting } \\
\text { Hailstone Velocity } \\
(\mathrm{m} / \mathrm{s})\end{array}$ & $\begin{array}{c}\text { Increase Compared } \\
\text { to Terminal Velocity } \\
(\%)\end{array}$ \\
\hline \multirow{12}{*}{6} & \multirow{4}{*}{0} & 0 & 31.29 & 0 \\
\hline & & 15 & 34.70 & 11 \\
\hline & & 20 & 37.14 & 19 \\
\hline & & 30 & 43.35 & 39 \\
\hline & \multirow{4}{*}{5} & 0 & 36.29 & 16 \\
\hline & & 15 & 39.27 & 25 \\
\hline & & 20 & 41.44 & 32 \\
\hline & & 30 & 47.09 & 50 \\
\hline & \multirow{4}{*}{10} & 0 & 41.29 & 32 \\
\hline & & 15 & 43.93 & 40 \\
\hline & & 20 & 45.88 & 47 \\
\hline & & 30 & 51.04 & 63 \\
\hline \multirow{12}{*}{10} & \multirow{4}{*}{0} & 0 & 40.40 & 0 \\
\hline & & 15 & 43.09 & 7 \\
\hline & & 20 & 45.08 & 12 \\
\hline & & 30 & 50.32 & 25 \\
\hline & \multirow{4}{*}{5} & 0 & 45.40 & 12 \\
\hline & & 15 & 47.81 & 18 \\
\hline & & 20 & 49.61 & 23 \\
\hline & & 30 & 54.41 & 35 \\
\hline & \multirow{4}{*}{10} & 0 & 50.40 & 25 \\
\hline & & 15 & 52.58 & 30 \\
\hline & & 20 & 54.22 & 34 \\
\hline & & 30 & 58.65 & 45 \\
\hline
\end{tabular}

\section{Conclusions}

There are numerous formulas and equations for the calculation of the terminal velocity of hailstones. The theoretical calculation in Equation (2) relies on various assumptions and values that have been investigated in this review of the literature. While often used as a seemingly good estimation in many testing procedures, the spherical shape of hailstones is questioned and proved to be inadequate in various publications considering this matter. The shape and surface properties of a hailstone affect its drag coefficient that significantly influences the terminal velocity of a given hailstone. Here, even the number and size of lobes have different effects.

Aside from the properties of the hailstones themselves, another significant effect is the air density. Changes in terminal velocity of up to $25 \%$ are possible over a reasonable range of air densities if other factors are unchanged. The effect of air density on the terminal velocity of hailstones and the resulting required adjustment for this factor in testing procedures based on the geographic location is one that has not been investigated thoroughly in the literature. It can be presumed that hailstorms at ground level or higher altitudes, where the air is less dense, can become more severe as the terminal velocity of hailstones can increase. Consideration of air density, humidity, pressure, and temperature do impact hailstone velocity but require very specific knowledge of each of these variables for more specific and refined calculations. Therefore, the geographical location for which hail impact tests are performed may be a new factor that should be considered. Photovoltaic modules located at higher altitudes may be exposed to more intense hailstorms of a given diameter hailstone than will occur at locations of lower altitudes.

The review also shows how the many assumptions resulting in empirical models that come from observations are often limited to a specific size range of hailstones. When comparing models that claim 
to cover a wide range of hailstone diameters, they yield significantly different results for the terminal velocity based on the used model.

Another effect that was investigated is the effect of wind on the resulting velocity of hailstones. Strong winds are a common accompanying effect with hailfalls. Wind can accelerate a hailstone above is terminal velocity, making this effect relevant for material testing and other fields that need to work with hail impact velocities.

No laboratory hail impact test standards or procedures recognize the effect of downburst velocities that might increase vertical velocities of hailstones. The discussion on the downburst effect is presented for information; no modification of iceball velocities is recommended. However, it is possible that in some hailstorms, downbursts may result in hailstones falling vertically at velocities exceeding still air terminal velocities. Effects of increased vertical velocities could become very important if a material is warranted to withstand hail of a given diameter and where that warranty is based upon the assumption that there is no downburst of air that increases a hailstone's velocity above $\mathrm{v}_{\mathrm{T}}$. Overall, the review shows a great deal of variability in hail events, thus elucidating the varied and often conflicting results and formulations in this field of study.

Author Contributions: The conception and design of the work were done by C.D. and M.S. C.D. worked on acquiring and interpreting data for the work while M.S. also contributed central ideas for Section 4 of this paper. M.B. provided significant revising and helped clarify notable findings in the conclusion and clarifications on hailstones' non-spherical shape. All authors have read and agreed to the published version of the manuscript.

Funding: This research received no external funding.

Conflicts of Interest: The authors declare no conflict of interest.

\section{References}

1. Fraile, R.; Berthet, C.; Dessens, J.; Sánchez, J.L. Return periods of severe hailfalls computed from hailpad data. Atmos. Res. 2003, 67-68, 189-202. [CrossRef]

2. Vinet, F. Climatology of hail in France. Atmos. Res. 2001, 56, 309-323. [CrossRef]

3. Webb, J.; Elsom, D.M.; Reynolds, D.J. Climatology of severe hailstorms in Great Britain. Atmos. Res. 2001, 56, 291-308. [CrossRef]

4. Lozowski, E.P.; Strong, G.S. On the Calibration of Hailpads. J. Appl. Meteorol. Clim. 1978, 17, 521-528. [CrossRef]

5. World Meteorological Organization (WMO). Technical Regulations: Volume II-Meteorological Service for International Air Navigation, 2018th ed.; World Meteorological Organization: Geneva, Switzerland, 2018.

6. National Weather Service. Severe Weather Definitions. n. d. Available online: https://www.weather.gov/ bgm/severedefinitions (accessed on 3 August 2020).

7. Kumjian, M.R.; Gutierrez, R.; Soderholm, J.S.; Nesbitt, S.W.; Maldonado, P.; Luna, L.M.; Marquis, J.; Bowley, K.A.; Imaz, M.A.; Salio, P. Gargantuan Hail in Argentina. Bull. Am. Meteorol. Soc. 2020. [CrossRef]

8. Schuster, S.S.; Blong, R.J.; Leigh, R.J.; McAneney, K.J. Characteristics of the 14 April 1999 Sydney hailstorm based on ground observations, weather radar, insurance data and emergency calls. Nat. Hazards Earth Syst. Sci. 2005, 5, 613-620. [CrossRef]

9. Noon, R. Forensic Engineering Investigation; CRC Press: Boca Raton, FL, USA, 2001.

10. Greenfeld, S.H. Hail Resistance of Roofing Products; Building Research Division, US Institute for Applied Technology: Washington, DC, USA, 1969.

11. Lucy, R.R.; Petty, S.E. Hail Damage Assessments to Low-Sloped Roof Systems. In Forensic Engineering: Damage Assessments for Residential and Commercial Structures; Petty, S.E., Ed.; CRC Press: Boca Raton, FL, USA, 2013; pp. 119-159.

12. Olson, R.; Juntikka, R.; Asp, L.E. High Velocity Hail Impact on Composite Laminates-Modelling and Testing. In Dynamic Failure of Composite and Sandwich Structures; Abrate, S., Castanié, B., Rajapakse, Y.D.S., Eds.; Springer: Dordrecht, The Netherlands, 2013; pp. 393-426.

13. E44 Committee. Practice for Determining Resistance of Solar Collector Covers to Hail by Impact with Propelled Ice Balls 2015; ASTM International: West Conshohocken, PA, USA, 2015. 
14. E44 Committee. Test Method for Determining Resistance of Photovoltaic Modules to Hail by Impact with Propelled Ice Balls 2019; ASTM International: West Conshohocken, PA, USA, 2019. [CrossRef]

15. F07 Committee. Test Method for Hail Impact Resistance of Aerospace Transparent Enclosures; West ASTM International: West Conshohocken, PA, USA, 2005. [CrossRef]

16. FM Approvals. Specification Test Standard for Impact Resistance Testing of Rigid Roofing Materials by Impacting with Freezer Ice Balls July 2005; FM Approvals: West Gloucester, RI, USA, 2005.

17. UL Standard. Standard for Impact Resistance of Prepared Roof Covering Materials 1/25/2010. Available online: https://standardscatalog.ul.com/ProductDetail.aspx?productId=UL2218 (accessed on 10 December 2020).

18. Schleusener, R.A.; Jennings, P.C. An Energy Method for Relative Estimates of Hail Intensity. Bull. Am. Meteorol. Soc. 1960, 41, 372-376. [CrossRef]

19. Long, A.B.; Matson, R.J.; Crow, E.L. The Hailpad: Construction and Materials, Data Reduction, and Calibration; Citeseer: Boulder, CO, USA, 1979.

20. Browning, K.A.; Ludlam, F.H.; Macklin, W.C. The density and structure of hailstones. Q. J. R. Met. Soc. 1963, 89, 75-84. [CrossRef]

21. Vittori, O.; di Caporiacco, G. The density of hailstones. Nubila 1959, 2, 51-57.

22. Insurance Institute for Business \& Home Safety. Impact Resistance Test Protocol for Asphalt Shingles. 2019. Available online: https://ibhs.org/wp-content/uploads/2019/06/ibhs-impact-resistance-test-protocolfor-asphalt-shingles.pdf (accessed on 24 October 2020).

23. Laurie, J.A.P. Hail and Its Effects on Buildings; Council for Scientific and Industrial Research: Pretoria, South Africa, 1960.

24. Petty, S.E. Synthetic Storm Damage (Fraud) to Roof Surfaces. In Forensic Engineering: Damage Assessments for Residential and Commercial Structures; Petty, S.E., Ed.; CRC Press: Boca Raton, FL, USA, 2013; pp. 161-182.

25. List, R. Zur Aerodynamik von Hagelkörnern. ZAMP 1959, 10, 143-159. [CrossRef]

26. Decker, F.W.; Calvin, L.D. Hailfall of 10 September 1959 Near Medford, Oregon. Bull. Am. Meteorol. Soc. 1961, 42, 475-481. [CrossRef]

27. Bilham, E.G.; Relf, E.F. The dynamics of large hailstones. Q. J. R. Met. Soc. 1937, 63, 49-62. [CrossRef]

28. Mandal, G.; Kumar, A.; Sharma, D.C.; Kumar, H. Comparative Analysis of Different Air Density Equations. MAPAN 2013, 28, 51-62. [CrossRef]

29. Böhm, H.P. A General Equation for the Terminal Fall Speed of Solid Hydrometeors. J. Atmos. Sci. 1989, 46, 2419-2427. [CrossRef]

30. Matson, R.J.; Huggins, A.W. The Direct Measurement of the Sizes, Shapes and Kinematics of Falling Hailstones. J. Atmos. Sci. 1980, 37, 1107-1125. [CrossRef]

31. Knight, C.A.; Knight, N.C. Hailstorms. In Severe Convective Storms; Doswell, C.A., Ed.; American Meteorological Society: Boston, MA, USA, 2001; pp. 223-254. [CrossRef]

32. Wisner, C.; Orville, H.D.; Myers, C. A Numerical Model of a Hail-Bearing Cloud. J. Atmos. Sci. 1972, 29, 1160-1181. [CrossRef]

33. List, R. Properties and Growth of Hailstones. In Thunderstorm Morphology and Dynamics; Kessler, E., Ed.; University of Oklahoma Press: Washington, DC, USA, 1982; pp. 409-445.

34. Prodi, F. Measurements of Local Density in Artificial and Natural Hailstones. J. Appl. Meteorol. 1970, 9, 903-910. [CrossRef]

35. Heymsfield, A.J. A Technique for Investigating Graupel and Hail Development. J. Clim. Appl. Meteorol. 1983, 22, 1143-1160. [CrossRef]

36. Heymsfield, A.J. The Characteristics of Graupel Particles in Northeastern Colorado Cumulus Congestus Clouds. J. Atmos. Sci. 1978, 35, 284-295. [CrossRef]

37. List, R. Kennzeichen atmosphärischer Eispartikeln: 1. Teil. J. Appl. Math. Phys. (ZAMP) 1958, 9, $180-192$. [CrossRef]

38. List, R. Kennzeichen atmosphärischer Eispartikeln: 2. Teil. J. Appl. Math. Phys. (ZAMP) 1958, 9, $217-234$. [CrossRef]

39. Olovsson, I. Snow, Ice and Other Wonders of Water: A Tribute to the Hydrogen Bond; World Scientific: New Jersey, NJ, USA, 2016. 
40. Allan, H.H. Properties of ice and supercooled water. In CRC Handbook of Chemistry and Physics: A Ready-Reference Book of Chemical and Physical Data, 95th ed.; Haynes, W.M., Ed.; CRC Press: Boca Raton, FL, USA, 2014; pp. 6-12.

41. Giammanco, I.M.; Maiden, B.R.; Estes, H.E.; Brown-Giammanco, T.M. Using 3D Laser Scanning Technology to Create Digital Models of Hailstones. Bull. Am. Meteorol. Soc. 2017, 98, 1341-1347. [CrossRef]

42. Knight, C.A.; Schlatter, P.T.; Schlatter, T.W. An Unusual Hailstorm on 24 June 2006 in Boulder, Colorado. Part II: Low-Density Growth of Hail. Mon. Weather. Rev. 2008, 136, 2833-2848. [CrossRef]

43. Giammanco, I.M.; Brown, T.M.; Grant, R.G.; Dewey, D.L.; Hodel, J.D.; Stumpf, R.A. Evaluating the Hardness Characteristics of Hail through Compressive Strength Measurements. J. Atmos. Ocean. Technol. 2015. [CrossRef]

44. Battan, L.J.; Wilson, D.S. “Hail” on a Mountain in Arizona. J. Appl. Meteorol. (1962-1982) 1969, 8, 592-595. [CrossRef]

45. Knight, C.A.; Knight, N.C. Quenched, Spongy Hail. J. Atmos. Sci. 1973, 30, 1665-1671. [CrossRef]

46. Morgan, G.M.; Towery, N.G. On the Role of Strong Winds in Damage to Crops by Hail and Its Estimation with a Simple Instrument. J. Appl. Meteorol. 1976, 15, 891-898. [CrossRef]

47. Torenbeek, E.; Wittenberg, H. Flight Physics: Essentials of Aeronautical Disciplines and techNology, with Historical Notes; Springer: Dordrecht, The Netherlands; London, UK, 2009.

48. Abraham, F.F. Functional Dependence of Drag Coefficient of a Sphere on Reynolds Number. Phys. Fluids 1970, 13, 2194. [CrossRef]

49. Heymsfield, A.; Szakáll, M.; Jost, A.; Giammanco, I.; Wright, R. A Comprehensive Observational Study of Graupel and Hail Terminal Velocity, Mass Flux, and Kinetic Energy. J. Atmos. Sci. 2018, 75, 3861-3885. [CrossRef]

50. Magono, C. Thunderstorms; Elsevier: Amsterdam, The Netherlands; Oxford, UK, 1980.

51. Macklin, W.C.; Ludlam, F.H. The fallspeeds of hailstones. Q. J R. Met. Soc. 1961, 87, 72-81. [CrossRef]

52. Dennis, A.S. Weather Modification by Cloud Seeding; Academic Press: New York, NY, USA, 1980.

53. Gokhale, N.R. Hailstorms and Hailstone Growth, 1st ed.; State University of New York Press: Albany, NY, USA, 1975.

54. Theis, A.; Borrmann, S.; Mitra, S.K.; Heymsfield, A.J.; Szakáll, M. A Wind Tunnel Investigation into the Aerodynamics of Lobed Hailstones. Atmosphere 2020, 11, 494. [CrossRef]

55. Wang, P.K.; Chueh, C.-C.; Wang, C.-K. A numerical study of flow fields of lobed hailstones falling in air. Atmos. Researc. 2015, 160, 1-14. [CrossRef]

56. Wang, P.K.; Chueh, C.-C. A numerical study on the ventilation coefficients of falling lobed hailstones. Atmos. Res. 2020, 234, 104737. [CrossRef]

57. Heymsfield, A.; Wright, R. Graupel and Hail Terminal Velocities: Does a "Supercritical" Reynolds Number Apply? J. Atmos. Sci. 2014, 71, 3392-3403. [CrossRef]

58. Heymsfield, A.; Szakáll, M.; Jost, A.; Giammanco, I.; Wright, R.; Brimelow, J. Corrigendum. J. Atmos. Sci. 2020, 77, 405-412. [CrossRef]

59. Heymsfield, A.J.; Giammanco, I.M.; Wright, R. Terminal velocities and kinetic energies of natural hailstones. Geophys. Res. Lett. 2014, 41, 8666-8672. [CrossRef]

60. Cheng, L.; English, M.; Wong, R. Hailstone Size Distributions and Their Relationship to Storm Thermodynamics. J. Clim. Appl. Meteorol. 1985, 24, 1059-1067. [CrossRef]

61. Huggins, A.; Crow, E.L.; Long, A.B. Errors in Hailpad Data Reduction. J. Appl. Meteorol. 1980, $19,733-747$.

62. Koontz, J.D. What Are the Effects of Hail on Residential Roofing Products? Available online: https://www.semanticscholar.org/paper/What-are-the-effects-of-hail-on-residential-roofing-Koontz/ e4d3f6c1a57462efdd39f5aa1ec740bf2809208e (accessed on 10 December 2020).

63. Morgan, G.M., Jr.; Summers, P.W. Hailfall and Hailstorm Characteristics. In Thunderstorm Morphology and Dynamics; Kessler, E., Ed.; University of Oklahoma Press: Washington, DC, USA, 1982; pp. 363-408.

64. Gessler, S.E.; Petty, S.E. Hail Fundamentals and General Hail-Strike Damage Assessment Methodology. In Forensic Engineering: Damage Assessments for Residential and Commercial Structures; Petty, S.E., Ed.; CRC Press: Boca Raton, FL, USA, 2013; pp. 23-67.

65. Knight, N.C. Hailstone Shape Factor and Its Relation to Radar Interpretation of Hail. J. Clim. Appl. Meteorol. 1986, 25, 1956-1958. [CrossRef] 
66. Picard, A.; Davis, R.S.; Gläser, M.; Fujii, K. Revised formula for the density of moist air (CIPM-2007). Metrologia 2008, 45, 149-155. [CrossRef]

67. Lemmon, E.W. Thermophysical Properties of Air. In CRC Handbook of Chemistry and Physics: A Ready-Reference Book of Chemical and Physical Data, 95th ed.; Haynes, W.M., Ed.; CRC Press: Boca Raton, FL, USA, 2014; pp. 6-15, 6-20.

68. Benson, T. Earth Atmosphere Model. 2014. Available online: https://www.grc.nasa.gov/WWW/K-12/rocket/ atmosmet.html (accessed on 29 May 2019).

69. Salby, M.L. Fundamentals of Atmospheric Physics; Academic Press: San Diego, CA, USA; London, UK, 1995.

70. DvS, R. A Giant Hailstone from Kansas in Free Fall. J. Appl. Meteorol. 1972, 11, 1008-1011.

71. U.S. Department of the Interior Geological Survey. Elevations and Distances in the United States; U.S. Department of the Interior Geological Survey: Washington, DC, USA, 2001.

72. Auer, A.H., Jr. Distribution of Graupel and Hail with Size. Mon. Weather Rev. 1972, 100, 325-328. [CrossRef]

73. Pruppacher, H.R.; Klett, J.D. Microphysics of Clouds and Precipitation; Springer: Dordrecht, The Netherlands, 2010.

74. Geerts, B. Fall Speed of Hydrometeors. Available online: http://www-das.uwyo.edu/ \{\}geerts/cwx/notes/ chap09/hydrometeor.html (accessed on 10 May 2019).

75. Knight, N.C.; Heymsfield, A.J. Measurement and Interpretation of Hailstone Density and Terminal Velocity. J. Atmos. Sci. 1983, 40, 1510-1516. [CrossRef]

76. Jenkins, D.R.; Mathey, R.G. Hail Impact Testing Procedure for Solar Collector Cover. STIN 1982, 83, 22841.

77. Changnon, S.A. Hail sensing and small-scale variability of windblown hail. J. Weather Modif. 1973, 5, 30-42.

78. Sioutas, M.; Meaden, T.; Webb, J.D. Hail frequency, distribution and intensity in Northern Greece. Atmos. Res. 2009, 93, 526-533. [CrossRef]

79. Browning, K.A. The Structure and Mechanisms of Hailstorms. In Hail: A Review of Hail Science and Hail Suppression; Foote, G.B., Foote, G.B., Knight, C.A., Eds.; American Meteorological Society: Boston, MA, USA, 1977; pp. 1-43.

80. Strauch, R.G.; Merrem, F.H. Structure of an Evolving Hailstorm, Part III: Internal Structure from Doppler. Radar. Mon. Weather Rev. 1976, 104, 588-595. [CrossRef]

81. Fujita, T.T. The Downburst: Microburst and Macroburst; The University of Chicago: Chicago, IL, USA, 1985.

82. Wilson, J.W.; Wakimoto, R.M. The Discovery of the Downburst: T. T. Fujita's Contribution. Bull. Am. Meteorol. Soc. 2001, 82, 49-62. [CrossRef]

83. Microburst. In An Illustrated Dictionary of Aviation, 1st ed.; Kumar, B.; de Remer, D.; Marshall, D.M. (Eds.) McGraw-Hill: New York, NY, USA, 2004.

84. Williams, E.; Boldi, B.; Matlin, A.; Weber, M.; Hodanish, S.; Sharp, D.; Goodman, S.; Raghavan, R.; Buechler, D. The behavior of total lightning activity in severe Florida thunderstorms. Atmos. Res. 1999, 51, 245-265. [CrossRef]

85. Savory, E.; Parke, G.A.; Zeinoddini, M.; Toy, N.; Disney, P. Modelling of tornado and microburst-induced wind loading and failure of a lattice transmission tower. Eng. Struct. 2001, 23, 365-375. [CrossRef]

86. Encyclopædia Britannica. Microburst. 2019. Available online: https://academic-eb-com.lib-e2.lib.ttu.edu/ levels/collegiate/article/microburst/52495 (accessed on 15 June 2019).

87. Holmes, J.; Oliver, S. An empirical model of a downburst. Eng. Struct. 2000, 22, 1167-1172. [CrossRef]

88. Kim, J.; Hangan, H. Numerical simulations of impinging jets with application to downbursts. J. Wind Eng. Ind. Aerodyn. 2007, 95, 279-298. [CrossRef]

89. Mason, M.S.; Wood, G.S.; Fletcher, D.F. Numerical simulation of downburst winds. J. Wind Eng. Ind. Aerodyn. 2009, 97, 523-539. [CrossRef]

90. Gunter, W.S.; Schroeder, J.L. High-resolution full-scale measurements of thunderstorm outflow winds. J. Wind Eng. Ind. Aerodyn. 2015, 138, 13-26. [CrossRef]

91. Choi, E.C.; Hidayat, F.A. Gust factors for thunderstorm and non-thunderstorm winds. J. Wind Eng. Ind. Aerodyn. 2002, 90, 1683-1696. [CrossRef] 
92. Lombardo, F.T.; Smith, D.A.; Schroeder, J.L.; Mehta, K.C. Thunderstorm characteristics of importance to wind engineering. J. Wind Eng. Ind. Aerodyn. 2014, 125, 121-132. [CrossRef]

Publisher's Note: MDPI stays neutral with regard to jurisdictional claims in published maps and institutional affiliations.

(C) 2020 by the authors. Licensee MDPI, Basel, Switzerland. This article is an open access article distributed under the terms and conditions of the Creative Commons Attribution (CC BY) license (http://creativecommons.org/licenses/by/4.0/). 